\title{
Youth Restiveness and Economic Development in Nigeria: A Study of Niger-Delta
}

\author{
Ezedikachi Ndubuisi Eze-Michael \\ Political Science and Public Administration, Babcock University, Ogun, Nigeria
}

\section{Email address:}

eze-michaele@babcock.edu.ng

\section{To cite this article:}

Ezedikachi Ndubuisi Eze-Michael. Youth Restiveness and Economic Development in Nigeria: A Study of Niger-Delta. Journal of Political Science and International Relations. Vol. 3, No. 3, 2020, pp. 70-83. doi: 10.11648/j.jpsir.20200303.14

Received: May 13, 2020; Accepted: June 17, 2020; Published: September 16, 2020

\begin{abstract}
Youth restiveness can fit the label as a sustained protestation embarked upon to enforce a desired outcome from a constituted authority. The youths constitute a force, that if their energies are properly controlled, there will be vast progress and improvement. Nevertheless, when such energies are degenerated on actions that are unfavourable, it results into crimes. Such crimes as hostage-taking of prominent citizens and expatriate oil workers, illegal oil bunkering and arms insurgency have all caused insecurity for business to thrive, thereby affecting economic development in Nigeria. It is in line with this, that the study examined youth restiveness and its impact on the economic development in Nigeria using Niger-Delta as a study. The study used the relative deprivation and the broken window theories as the theoretical framework. The research adopted qualitative method. The population was the youths in Nigeria, particularly in the Niger-Delta. This part of the country was purposively selected because the youth in this area constituted the major restive behaviour witnessed in Nigeria between 2010 and 2018. Data were collected through documentary review (of publications on youth restiveness) as well as journals, and materials from the internet. Findings showed that the nature of most youths that engage in youth restive activities in the NigerDelta do not have access to formal education; these youths are majorly unemployed and poor. Also, the institutional effort of the government in eradicating youth restiveness has proven incapable of alleviating the critical situation and that the governments' lack of leadership and discipline has hindered the eradication of youth restiveness. Furthermore, the effect of youth restiveness on the economic development in Nigeria has cost the nation its stability, general improvement, cultural integrity, likelihood of survival and its preservation of national value. The study concluded that youth restiveness is a serious issue that has affected Nigerian state in the negative. It caused a drastic reduction of per capita increase of the nation's production which forms the basis for economic development. It was recommended that, government should pay more attention to the needs and demands of the less privileged youths in the country by giving them scholarships, entrepreneurship loans and skill acquisition programs. This will engage them in legitimate works and prevent any form of idleness. There should be an enlightenment campaign against youth restiveness, as this will make citizens become more educated on the damage youth restiveness can bring to the society.
\end{abstract}

Keywords: Economic Development, Niger-Delta, Youth, Youth Restiveness

\section{Introduction}

Youth restiveness is the extreme form of deviant behaviour among youths which is socially unacceptable in any society [1]. Restiveness, being an attribute of youthful exorbitance, is a global phenomenon that is challenging [2]. It could also be a combination of any action that constitutes unwholesome, unacceptable activities engaged in, by the youths in any given community [1]. Basically, the development of youths is meant to be one of the priorities of any country as they are being groomed to become leaders of tomorrow. The youths constitute a force, that if their energies are properly controlled, there will be vast progress and improvement. Nevertheless, when such energies are degenerated on actions that are unfavourable to national development, such a country will definitely experience multitudes of difficulties.

There has been increase in the occurrence of violence and lawlessness, hostage-taking of prominent citizens and expatriate oil workers, as well as oil bunkering, arms insurgence, cultism in the Niger Delta region in Nigeria. 
Most Nigerians believe that unavailability of jobs, corruption, weakness of governance have contributed to and motivated the youths of the country into engaging in such unlawful acts. According to Lamido [3], these are mostly the activities of youths that are socially rejected and motivated by enforced desired outcome from the constituted authority. The task of bringing up the young, making members of the society in terms of culture, and imbibing positive attitudes and behaviours normally begins at home and continues in school. This situation is normally described as socialization [4]. Some of these tasks are not carried out and the outcome is producing youths who have over ambitious desires. This has made an impact on Nigeria's economic development in terms of security, access to convenience of life, stability, cultural integrity and others, and has become one of the challenges facing people in the present Nigeria.

Economic development represents the per capita increase in the production of a country. Winston [5] explains that economic development shows the excess of consumption and production of a country as compared with increase in population. This increase in population is due to better combination and increase in the productivity of the factors of production. Amartya [6] said that economic development is about creating freedom for people and removing obstacles to greater freedom and also said that greater freedoms enables people to choose their own destiny. Obstacles to freedom, and hence to development, include poverty, lack of economic opportunities, corruption, poor governance, lack of education and lack of health.

One of the reasons why youth restiveness has to be addressed in Nigeria is because of the relevance of youths in the society. As was said before the way in which youths turn out affects the society and national development. What makes the youth so important is that they are a big reservoir of labour and the most vibrant age bracket in human population and the marrow of the human resource of any country [7]. With their workforce capability and imaginative capacities, a nation makes massive steps in economic development and socio--political achievements.

Youth restiveness has become a major problem in Nigeria. Its rapid increase has brought about a lot of distress in the country, such that it enhances terrorism and other unlawful crimes. Crimes such as hostage taking of citizens and expatriate oil workers, oil bunkering, arms insurgence, cultism have all had effect on the economic development of the Nigeria. It is against this backdrop that the study examines youth restiveness and its impact on the economic development of Nigeria using Niger-Delta as a study between 2010 and 2018.

\section{Review of Literature}

\subsection{Understanding the Concept of Youth Restiveness}

Restiveness among youth has become one of the worldwide occurrence and those in Nigeria has been on exceptional surge. Youth restiveness according to Abudah [8] is a self-generating theory of conflict process within social group and he further stated that any restive acts of groups whether inter or intra in nature in contemporary history of Nigeria is synonymous to conflict. Elegbeleye [9] sees youth restiveness as a sustained protestation embarked upon to enforce desired outcome from a constituted authority by an organized body of youths. Youth restiveness involves the combination of actions, behaviours, attitudes exhibited by youths which are socially unacceptable and unwholesome in the society and it has being a device through which youths use to obtain what they want from the relative authority [1].

On various cases unparalleled violence, the cases of kidnapping, abduction and cruel destruction of valued structures as well as lives and personal properties has occurred a lot. These are mostly the activities of youth that are publicly intolerable caused by imposed desired result from the established authority. It is commonly reported that poverty, unemployment and education amid others are accountable for this high level of insecurity decided by youth restiveness in the form of bombing mosques, churches, markets and killing of innocent people. The occurrence of insecurity has become one of the main worries of the citizens in Nigeria especially in the northern part of the country. These occurrences are similar actions characterised by killing and kidnapping of oil workers in Niger-Delta area. The problem disturbing Nigerian is insecurity demonstrated by the activities of youth and this has affected the sustainable development of the country.

\subsection{Causes of Youth Restiveness}

It is often said that an idle hand is the devil's workshop. Various studies have recognised factors guilty for youth restiveness. It therefore confirms the fact that youth who engage in nothing resort to vices that are capable of disturbing the social order of a well-organized society. Most people believe that youths are responsible for their restiveness but they are forgetting the fact that certain situations contribute to these behaviours. A lot of factors have been identified such as lack of humanitarian and social welfare, unemployment, lack of good governance, corrupt practices of government officials, inadequate training programmes, lack of provision of employing establishments, inadequate recreational facilities, and lack of quality education.

\subsubsection{Lack of Humanitarian and Social Welfare}

The Niger Delta has contributed immensely to the growth of the nation giving the nation it's all without requesting any reward. Constant oil survey and contamination have totally ruined the environment and can barely withstand the means of living and source of income of the people, loss of plain infrastructure and social amenities such as, roads, schools, electricity, pipe born water and hospitals. For some people in the region who are farmers and depend on the produce of their farm to survive their farmlands have been destroyed and rendered useless and even the people's sources of drinking water are polluted by constant oil spillages and the air they 
breathe is unsafe due to gas flaring and emission of carbon monoxide and other noxious emissions that are daily released into the air due to oil and gas exploration activities. The Niger Delta region and the people who reside in it are therefore bombarded from the air, land and water. The region is said to be one of the most underdeveloped and poor oil producing regions in the world. Thus events like this causing youth restiveness.

\subsubsection{Unemployment}

Unemployment has always been one of the problems in Nigeria. According to Osalor [2], unemployment is a hydraheaded monster which exists among the youths in all developing countries. The unemployment rate in Nigeria was last reported at 23.9 per cent in 2011. The national bureau of statistics has put the figure of unemployed Nigerians in the first half year at 23.9 per cent, up from 21.1 per cent in 2010 and 19.7 per cent in 2009. The rate or number of unemployed youths in the country is increasing day by day as more youths are graduating from the university each passing year while some are being relieved from work and there is lack of provision of employing establishments.

Zakaria [10] believes that "the rising tide of unemployment and the fear of a bleak future among the youth in African countries have made them vulnerable to the manipulations of agents' provocateurs". These controlling causes include wounded politicians, gluttonous groups who use these youths as thugs to attain their desires, religious exploiters. And it is shown that the absence of job opportunities in developing countries is guilty for youth restiveness with tragic and catastrophic results.

\subsubsection{Bad Governance}

Good governance is required for the growth and development of any nation. Regrettably, in Nigeria bad governance is more public than good, ensuing in disorganized development. The World Bank [11] identifies the main characteristics of bad governance, failure to properly distinguish between what is public and what is private, leading to private assumption of otherwise public resources; incapability to form a expected frame work for law and government behaviour in a manner favourable to development, unnecessary rules, regulations, authorizing requirement and so forth which obstruct the operational of markets and boost rent-seeking; main concerns that are unreliable with growth and development, which results to misallocation of resources; and very constricted base for, or non-transparent, conclusion making. It has been noticed that past and present administrations of government have not really allocated much to the demands of the youths and that most of the funds meant for the youths have been embezzled by government officials and used for their own greedy desires. These makes the youths restive and engage in forms of violence when they perceive that resources meant for them are being wasted by those in authority.

\subsubsection{Poverty}

Studies have shown that Nigeria happens to be one of the poorest countries in the world with a poor economic development. Poverty means difference and societal inequality and this hurts the poor. More than 70 per cent of the Nigerian people are said to be living in miserable poverty and living below the poverty line, and more than or one-third survive on less than one US dollars a day (350 naira). This includes lots of youth in built-up centres in Nigeria who scuffle to earn a living by being shoe shiners, cleaning cars, hawking food stuffs, cleaning and writing materials and even hawking clothes by the road side etc. and hardly the profit from the sales can keep them living above the poverty line. Disappointed, dissatisfied, unfulfilled, and miserable, they try to find a chance to express their anger against the state and therefore resort to protests against the government, violence like destroying public property and unlawful acts like kidnapping, killings etc.

\subsection{Concept of Economic Development}

Economic development is the process by which developing economies become advanced economies. In other words, the process by which countries with low living standards become nations with high living standards, their economic development gets improved. Arthur Lewis [12] said that economic development represents the per capita increase in the production of a country. Winston Salem [5] explains that economic development shows the excess of consumption and production of a country as compared with increase in population. This increase in population is due to better combination and increase in the productivity of the factors of production. Amartya Sen [6] said that economic development is about creating freedom for people and removing obstacles to greater freedom and also said that greater freedoms enables people to choose their own destiny. Obstacles to freedom, and hence to development, include poverty, lack of economic opportunities, corruption, poor governance, lack of education and lack of health.

Economic development is about an extended average life expectation, enhanced efficiency, higher knowledge and learning rates, and better public education.

Put simply; economic development is all about improving living standards of a country and the people in it. Improved living standards include increase in life expectancy, income, education and literacy level. It is also the process in which an economy grows or changes and becomes more advanced, especially when both economic and social conditions are improved. It is also the process whereby simple, low-income national economies are transformed into modern industrial economies. The theory of economic development how simple and poor economies can evolve into sophisticated and relatively prosperous ones it is of critical importance to underdeveloped countries, and it is usually in this context that the issues of economic development are discussed.

\subsection{Indicators of a Good Economy}

The extent to which a country has developed may be assessed by considering a range of narrow and broad 
indicators.

\section{Natural resources}

Finding of new natural resources like oil, or mineral deposits boosts economic growth as this shifts or increases the country's production possibility curve other resources include land, water, forests and natural gas.

\section{Education}

Institutions, systems, tools and facilities that support the acquisition of knowledge and skills are created. The percentage of those aged 15 and above who are able to read and write a simple statement on their everyday life.

Law

There is a fair law system in which the legal system is open minded, reasonable and unbiased, reasonable and impartial and the rules are followed. Law an institutional framework which regulates economic activity such as rules and laws. There is no specific set of institutions that promote growth. Other indicators may include health and wellness, safety of citizens, respect for Human Rights, political stability, human capital and information technology.

\subsection{Economic Development and Youth Restiveness}

The importance of economic development to the objectives and goals of a nation cannot be over emphasized. This study examines youth restiveness in the Niger -Delta region of Nigeria, and the challenges it poses to Nigeria's democracy, economic development and foreign investment causing Nigeria to become a theatre of violence. Threating the social security of the country, with its oil resources which accounts for about 70 per cent of the nation's revenue, the Niger-Delta has become more or less the setting of the Nigerian economy. Most people have pondered why youth restiveness happens in this region.

From 1999 youth restiveness in the Niger Delta procured a fresh aspect. The new method of militancy and restiveness include, kidnapping of foreign oil workers, kidnapping of top officials in government and those supporting government, firebombing, murder, and other forms of horrid killing.

Elaigwu [13] in his contribution to the dialogue on the Niger-Delta said that "despite being the goose that lays the egg for the nation, the Niger delta is generally viewed as a region suffering from youth militancy, split by internal strife, damaged by never-ending conflicts between local communities and oil producing multi nationals, embellished by high profile kidnapping events and also added that what makes Nigeria comfortable is the Niger delta but those in the Niger delta are not comfortable at all" On June 23rd 2012, Saturday Vanguard reported that a family of six as well as a six-month old child and a 70 year old grandmother were viciously massacred by hit men in Plateau State. There are also incidences of abduction and the victims are usually close relatives of significant members of the public such as commissioners, ministers and former governors. The effects of the disasters on the economy are clear, existent and intensely stinging, to the point that the crises have almost disabled the present government of President Muhamadu Buhari. Logically too, the unfavourable economy has made
Nigerians to continue accusing the present government. The transformation repetition of the APC/Buhari Government is now connected with poverty and suffering even in the most uncommon places.

Youth restiveness can be categorised into four, the first is the group that is driven in the direction of honest campaigning for the moralities and re-establishment of selfesteem to the Niger-Delta. A characteristic instance was the effort of the survival of the Ogoni people led by late ken Saro Wiwa. The late social critics midst other eight Ogoni sons were assassinated by the late Sani Abacha's government. The second group of youths are those who engage in sovereignty competition among one another, in an attempt to the achievement of government's acknowledgment. Intra group restiveness occurs when there is a competition for an interest. This majorly always results to conflict. The third group is made up of youths who engross themselves in self-centred and unlawful actions such as armed robbery, oil bunkering, and other scandalous misconducts. They are also being used as political thugs by people in power for the purpose political corruption. The last group is made up of youths who are on a vengeance task for being used to get to power and not being compensated after the politician attains such power.

One of the significance of this study is to reinstate the dependence of disregarded youths in the region as an essential phase in the direction of amity and development in the country as youth restiveness has made great harms than good in the region on national development in the country, emphasising the effect of conventional elite politics and the oil centric political economy categorised by the failure, abandonment and the domination of the oil manufacturing societies of the youths in the region.

\section{The Ogoni Land Clean-Up}

The Federal government of Nigeria processed the award of contracts for the clean-up of Ogoni land. The Ogoni land area in the rivers state which is the oil boom of the country has been vandalized by oil leaks leading to the destruction of surrounding waters and farm lands. The oil pollution in the Ogoni land had led to destruction of mangrove and aquatic lives in the area. A UNEP report after scientific study suggested total clean-up of the land saying that the amount of water and environmental pollution of the rivers societies were upsetting and shocking. The report about the condition of the Ogoni land was initially stated in 2011 during the Goodluck Ebele Jonathan administration but little or nothing was done about it. Shortly after the resumption of the President Muhammadu Buhari administration in 2015 the clean-up exercise was launched but recent investigation by premium times showed that despite the official claims the clean-up was yet to start. The federal government had claimed to raise the sum of $\$ 177 \mathrm{~m}$ out of the $\$ 1 \mathrm{bn}$ required for the clean-up its main source of fund being from the companies that extracted oil from the land especially SHELL.

The Ogoni land is a community that has sustained their economy through farming and fishing. The takeover of their land by multi-national companies caused environmental degradation. The people complain of their land being 
completely destroyed by the search for oil; streams and creeks are totally and continually polluted; the atmosphere is for ever charged with hydrocarbons, carbon monoxide and carbon dioxide; many villages experience the infernal quaking of the wrath of gas flares. The people say that they always breathe and live with death all around them.

The Ogoni land Clean-Up in Relations to Youth Restiveness

Fegalo Nsuke, public secretary of the movement for the survival of the Ogoni people in a meeting with the youth leaders of the National youth council of the Ogoni people spoke out and said that "the Ogoni clean-up would end up as Nigeria's biggest scam if left the way it is presently structured". He later went ahead to say that the HYPREP was desperate to spend money and not bothered about the welfare of the Ogoni people. The federal government had earlier ordered the evacuation of the Ogoni people from the land to commence clean up but Fegalo Nsuke warned that the impact of evacuation and cleaning of the massive spill situation would be counterproductive without providing substitute sources of water for the people. The drama around the cleanup of the Ogoni land is therefore enhancing youth restiveness because youths of the Ogoni land feel that the federal government does not pay enough attention to their welfare. They sensed that the only reason that the government pays them attention is because the Ogoni land is one of the areas that produce oil for the country. Federal government had promised the Ogoni people of clearing of their land which has not been executed till now. Like Nsuke said they are of the opinion that the clean-up of the Ogoni land is just an idea brought up so that the people can have the belief that the government has them in mind and use the project funds as an avenue for corruption. Among the agenda of the clean-up project was that the Ogoni people would have to evacuate their land. The government therefore did not provide alternatives for these people when most people source of income is living in that land.

\subsection{Relative Deprivation Theory}

The relative deprivation theory is profoundly rooted in the Psychological variables of anger and frustration and deprivation which is the basic Product for conflict and restiveness of any kind [14]. Relative deprivation is the lack of resources to tolerate the nutrition, lifestyle, activities and facilities that an individual or group are familiar to or that are generally encouraged or accepted in the social order to which they belong i.e. intense deprivation occurs and the further extensive and intense deprivation is between members of a population, the greater the degree of violence in which ever form. Relative deprivation may also emphasise the individual involvement and understanding of dissatisfaction when being deprived of something to which one believes oneself to be permitted to, however accentuating the perspective of the individual makes objective measurement problematic. The idea of relative deprivation has important penalties for both behaviour and attitudes, including political attitudes, and participation in collective action.
One of the pioneers of the relative deprivation theory Gurr [15] contends that relative deprivation is the distinction between ones value expectations and value capabilities. Gurr further evaluates that youth violence is a normal thing. Coleman [16] argues that the unequal socio-economic development of the various ethnic groups in Nigeria led to inter-ethnic and intra ethnic conflict. Coleman also states that once there is an uneven development in all or some facets of human existence within a given society, the different groups will definitely become immersed in the competition for the goods of modernity which consistently leads to a conflict situation. Asobie [17] says that there are roughly 300 spills per year in the Niger Delta region. The oil multinational corporations that operate in the region are partly to blame for the restiveness for they are not committed to the dilemma of their host communities. Some the oil multinational corporation and Federal Government of Nigeria are occupied in the association of militarizing the Niger Delta region. In the late Saro-Wiwa's view [18] the root causes of conflicts in the Niger Delta are unequal distribution of revenue, unequal development among the Niger Delta region.

Relative Development Theory refers to the dissatisfaction people feel when they compare their positions to others and realise that others in the group possess something that they do not [19]. When this feeling persists, it may lead to frustration, stress and aggression, which may result to violence.

\section{Broken Window Theory (BWT)}

This theory was proposed by James Q. wilson and George L Kelling. Wilson and Kelling [20] contributed to the broken windows theory of crime. They assumed the analogy of 'Window-Building' to shape how inconsequential violent act may lead to main intense and violent acts if not legitimately attended to by the security agencies. If the first broken window in a building is not mended, the overall population who like breaking windows would assume that nobody cares about the building and more windows would be broken and if this continues the building would have no windows [20]. What the theory is trying to state is that where any violent act of protest has gone unopposed or not legitimately managed by the appropriate security agencies, it would create more violent acts. The theory recommends that signs of physical illness (such as illegal dumpsites, broken-down buildings,

Lack of security patrol, and unplanned structure) in a neighbourhood can prompt such neighbourhood to violence. The fundamental assumption of the theory is that physical disorder in a neighbourhood can invade the ways in which residents can exercise social control. Therefore, lack of social control makes the neighbourhood inclined to social disorder activities such as public drinking, gambling, and prostitution. The idea was that low-level crime should not be tolerated and severe penalties needed to be given for anti-social behaviour and minor vulgarities in order to discourage more serious crime and ensure that communal morality and social harmony is maintained by clear limit maintenance.

Unfortunately, these activities further attract illegal profitable criminal enterprises such as drug dealing and raise 
the level of violence in the neighbourhood.

\section{Nigerian Youths and Nigerian Economy}

The British colony ruled the Nigeria prior to her independence close to 100 years to exploit the nations abundant natural resources required for the sustenance of its empire. For the duration of this colonial era, the major source of the earnings in the foreign exchange market was the trading of agricultural commodities. The colonial masters were interested in boosting their economy as they promote the export of agriculture production and trades were used as the drivers of the colonial economy [21]. They put in places several measures to stimulate the production of industrial raw materials such as palm oil and kernels, cocoa, cotton, groundnut and rubber. However, the promotion of agricultural production export increased the problem of food insecurity due to the fact that farmers couldn't cope with the mass production as a result of inefficient traditional technologies [21]. Furthermore, the colonial era further exploit other mineral resources such as tin, coal, columbite, gold and petroleum. Nigeria's economic growth stability is a suggestion that the nation is edging closer to its long-run steady shape balanced growth path [22].

Yusuf [23] stated that Nigeria operates a mixed economy system and an ever-rising market filled with intensifying production, technology, service, financial, communications and entertainment industries. The Nigeria economy is rated the largest economy in Africa and 27th largest economy in the world. Furthermore, the nation $60 \%$ of her revenue come from oil in which Nigeria produces about $2.7 \%$ of the world's oil supply [24].

According to the CBN Annual Report [25], the United Nations sponsored a longer-term program to enhance Nigeria economic development, this shows that the country is committed to attaining a broad wider scope of motivating goals and objective which includes eradicating poverty, improving education standard, eliminating gender inequality, improving health condition, conducive environment, and international development cooperation which statistics revealed that progress was made. However, the economy still lacks and suffers in areas such as power, insecurity, unemployment, governance etc despite the country ranking the most rapid developing economy.

\subsection{The Current State of Nigerian Youth}

Asamu [26] stated that the youth are the foundation for development of a country, however, in a country with a population of over 190 million people and an average of 18 years revealed that the most active segment of Nigeria comprise of the youth. Abdullahi, Mohammed and Casey [27] expressed an opinion that the proper connection of youth strength, modernisation, personality, energy and point of reference will develop a nation. This means that Nigeria can make advancement through creativity and productivity of the youthful population. Haruna and Jumba [28] also indicated that youth activity and inactivity can either determine progress or decline the dominance and structure of a community. In view of this some particular industries in Nigeria have been penetrating the international market through the youth endeavour such as the fashion, entertainment, and business, academic and so on and as a result as earned the partnership of the United Nations and Nigeria youth. Despite the partnership by the United Nations and other programs in place to improve the youths of the nation, the issue of unemployment cannot be undermined.

Nigeria youth are faced with the challenge of unemployment and underemployment, which has hindered their contribution in nation building. Yahaya [22] stated that over $60 \%$ of youths who are capable of working are unemployed. This is however an alarming situation which seems uncontrollable as the rate of unemployment among youth gets worsened and leads to poverty. As a result, the unemployed youth lives a life of poverty and lack for the reason of non-sustenance of self. Chukwuemeka [29] asserted that unemployed youth are eligible to become deterioration, disunity, socio-economic disruption and can even become problematic for growth to flourish. Nigeria youths wander around in search of better opportunities. Unemployed youth ends up becoming smugglers, thieves, fraudsters, drug dealers, oil mafias, political thugs without contributing any share to humanity rather causing it backwardness socially and economically.

\subsection{Challenges Facing the Youth in Nigeria's Emerging Economy}

Nigeria today is plagued at the moment with strenuous, exhausting and unprecedented challenges in the field of socio-economic growth and development [29]. The dilemma new graduates face is the issue of work experience before gaining full employment. These graduates with no work experience tend to spend more years being unemployed, which creates gap in experience and loss of skill in work environment [30]. With a few exceptions, this unemployed are motivated to resort to crime, or engage in entrepreneurial exercises that is more likely to fail due to the unfavourable market system and policies in place.

The issue of inequality is another challenge that threatens the youth in developing in a nation. Mutiba [31] states that over 500 million people are living on a daily consumption of less than $\$ 2$ dollars per day. He further stated that youth employment growth rate was the first time since the emergence of global economic recession that inequality increased. Ifidon and Ahiauzu [32] stated that majority of youths lack access to basic fundamental human right and many youths are not offered the opportunity to maximise their potentials. These inequalities could include access to quality education, healthcare, job employment, technology, and many others. These factors contribute to the reasons why there is failure in the system of empowering youths. Chukuezi [33] revealed that other challenges includes insecurity, non-accessibility to loan, lack of quality education, 
political instability tends to disrupt youth crave for selfsufficiency and development. In view of these, the challenges youths face results to violence actions, restiveness and fraudulent act, among other things and directly influence the economy negatively.

\subsection{Result of Youth Restiveness in Nigeria}

Yusuf [23] clearly stated that youths are endowed with energy and if positively channelled can result to high productivity, therefore, youths will be capable of contributing to growth and expansion of the society while if negatively channelled, can result to restiveness which can dent the society as well. Chika and Onyene [34] observed that a restive person is an uncontrolled person especially as a result of being bored or unsatisfied with changes in circumstances, or decisions or policies. This can result to mixture of actions, performances and behaviour that comprises unpleasant, socially intolerable behaviour displayed by youths in the society. Okaba [35] stated that youth restiveness can yield three major outcomes which include security, social and economic outcomes.

Security Result

Restiveness cut off the youth from taking the likely role as tomorrow leaders. This is as a result of numerous lives of innocent beings that have being lost or displaced from their place of abode [36]. Mutida [31] indicated that the restiveness deteriorate to war that may grossly cause the breakdown of the country. A practical example is the Nigerian civil war which occurred in 1967 till 1970, where millions of Nigerians lives were lost. Furthermore, not only lives were lost but displaced as well as worth of properties were destroyed. A movement prompted as a result of restiveness among youth. Also another example is the Northern part of Nigeria dominated with crisis over the insurgency of Boko Haram. Youth restiveness leads to insecurity and instability. The insecurity has infuriated nonstop cases such as abduction, kidnap, movement restriction and explosion of arms, human right violation and explosives [36]. According to Ofem and Ajayi [37], Nigerian military forces extra prudently put to death more than 1200 people; they have subjectively arrested and some people have died in detention in the itinerary of security functions against Boko Haram. Boko haram is group that disrupt the security of Nigeria most especially in the Northern part of the county which had cursed insecurity panic and weakness. Also, report evidently revealed that little or no respect for integrity of the human in Nigeria exists. Ndu [36] stated that Nigerians are subjectively disadvantaged of life and freedom.

\section{Economic Consequences}

Youth restiveness negatively influences the growth and expansion of the country. This can be demonstrated in the low industrial outcome and low human capital development. Furthermore, the amount of infrastructure and other possessions damaged, oil pipelines vandalized cannot be measured. Youth restiveness worsened poverty in Nigeria in view of the fact that youth restiveness results to negative effects, the mandatory human capital for creating. Youth restiveness can leads to interference in production, distribution and consumption which are outcomes for creating wealth for the state. Emaduku [38] stated that Nigerian economic was disrupted by Boko Haram who has a result of their insurgency had discouraged investment into Nigerian economy. Trillions of naira had been lost in form of Foreign Direct Investment (FDI), also businesses have been lost, destroyed and wrecked in the areas of Boko Haram operations.

The Conceptual Framework Showing How Youth Restiveness has Challenged Nigerian Security and its Effects on the Development of the Country.

Table 1. Showing how youth restiveness has challenged Nigerian security and its effects on the development of the country.

\begin{tabular}{lll}
\hline Youth restiveness & Nigeria's security & Sustainable development \\
\hline Violence & Preservation of national value & Stability \\
kidnapping & Cultural iantegrity & General improvement \\
Bomb blast & & Access to convenience of life \\
Abduction & Likelihood of survival & \\
\hline
\end{tabular}

Source: Yusuf A. Y (2014) Youth Restiveness: Nigeria's Security and Sustainable Development.

\section{Social Consequences}

Youth restiveness disrupts social order in the society. According to Onyekpe [39] the youth restiveness has resulted to social vices and crimes such as keeping gangs, cultism, rape cases, abduction, armed robbery, criminal behaviour, and so on. As a result, Chukwuemeka and Aghara [40] writes that the attack of the multinational oil associations by restive youths and the associated invasion of foreign nationals such as kidnapping and abduction in the Niger Delta region, to the horrible killings by Boko Haram in the Northeast, to the Fulani Herdsmen in the North central, and the various robbery cases and clashes of cultist places like Lagos and Calabar, are prototypical social cost of youth restiveness in Nigeria.
Economic growth or development of a nation can be seen based on the standard of living of the citizens within the nation. However, the recognition for the role of youth in the economy growth and development cannot be inevitable all over the world. Despite this recognition, nothing has changed in terms of particular government policies that can be aimed at accommodate the youths to bolster the economy in the future.

\section{Restiveness Among Niger-Delta Youths}

\subsection{Nature of Youths Restiveness in Niger-Delta, Nigeria}

The Niger Delta region is pigeonholed with violence and 
conflict which varies from ethnicity to religious, economic, political patronage and accommodation issues [41]. According to Inyang [42], the armed conflicts between the Niger-Delta youths and Nigerian government are majorly the access to the oil fund. The conflict over oil resources control has assumed different aspect overtime, which has encouraged youth restiveness in the Niger-Delta region. The Niger Delta region which is unarguably the foundation of the oil industry in Nigeria filled the news for an extensive period of time as the youths of that region tried numerous means of getting government and oil companies to pay attention to their dire conditions of living and ease their sufferings since according to them, the resources which is building the nation is flowing from their land so by asset of that they should also be partakers of its benefits [41].

These youth organisations in the Niger-Delta region protested and demanded against environmental filth, for enhanced development of their area from oil generated revenue ensued to them, for the total neglect thereby and accused government of economic disempowerment. Chika and Onyene [34] stated that the neglect, environmental degradation and disempowerment resulted to poverty with different dimensions described as being in a state of lack of physical necessities, assets and income. The incidence of poverty in the Niger Delta has been on a steady increase in about the last three decades. Also, according to Elegbeleye [9], the Niger Delta people face the issue of unemployment, underemployment and underdevelopment. However, the region was described recently as a major unsafe, insurgent, raging and violent region in sub-Saharan Africa. This contention led to a rise in abduction and destroying of oil pipelines as well as other evils that were being perpetrated. After a period of years, the Nigerian government intervened and the Amnesty program was created to help deliver some of the promises which government had made to the youths in those areas [43].

In view of this, the Niger Delta people is rather prompted largely by the environmentally negative activities of oil and gas of Multinational companies, as well as accounts greatly for the high wave of violence, and insecurity experienced in the Niger Delta region. The Niger Delta youths in rebellion and in an attempt to create fairness, have side-tracked their energies to kidnapping and abduction of overseas (and sometimes local) oil workers for ransom as authentic means of livelihood. Other brutal activities carried out by Niger Delta youths include; crude oil bunkering, pipeline vandalism and stealing, because of poverty and unemployment [44].

\subsection{State of Youth Restiveness in Niger-Delta}

Youth restiveness in Nigeria has been a noticeable topic in current times. There has been an increase in the happening of acts of violence and anarchy (state of lawlessness), including kidnapping of citizens and oil workers, as well as oil bunkering, arms rebellion, cultism, etc., especially in the Niger Delta region. Nevertheless, youth restiveness is not a recent wonder. Various forms of youth restiveness that are economically, politically, or religiously motivated have existed for a long time [41].

Youth restiveness refers to excess of activities expressed in the form of hostage taking of foreign nationals, local oil workers and citizens for ransom; oil pipe-line blow ups; illegal bunkering; peaceful or violent demonstration; bombing of public places, etc, in the Niger Delta of Nigeria [45]. The new form of militancy and restiveness include, kidnapping of foreign oil workers, kidnapping of top notches in government and those supporting government, burning, assassination, and other forms of horrible murder.

Restiveness according to Abudah [8] is a self-generating theory of conflict process within social groups. He further stated that any restive acts of groups whether inter or intra in the nature of contemporary history of Nigeria is synonymous with conflict. Intra group restiveness or conflicts occurs when there is a competition for an interest [34]. The relative deprivation theory asserts that psychological variables and deprivation is the basic product for conflict and restiveness of any kind. The more widespread and intense deprivation is among members of a population, the greater is the magnitude of violence in one form or the other [34]. Chika and Onyene [34] argued that the unequal socioeconomic development of the various ethnic groups in Nigeria led to inter-ethnic and intra ethnic conflict. Once there is an uneven development in all or some facets of human existence within a given society, the different groups will definitely become immersed in the competition for the goods of modernity which invariably leads to a conflict situation. Asobie [17] says that approximately 300 spills per years in the Niger- Delta region and blames restiveness of the Niger-Delta youths on the oil multinational corporations that operates in the region that is not committed to the plight of their host communities.

\subsection{Causes of Youth Restiveness in Niger-Delta}

The Niger-Delta being an oil rich region of Nigeria happens to be the region with country's source of income and economic well-being of the nation. Despite this statement, the youths are of the opinions that little contribution has been made to region as the region lacks good roads, poor communication, education, and health facilities as well as lack of potable water and even arable land [43]. This implies that the economic well-being of the people is affected as oil spillages is the order of the day. Oil companies operating in the area are often held responsible for the plight of the people of the Niger Delta and therefore suffer attacks, which results in abduction of staff and vandalisation of facilities [42]. The sharp contrast in the standard of living between the indigenes and staff of oil companies is a source of envy.

Another reason for Youth Restiveness in Niger-Delta is the pollution of oil as a result of spillages in the region. Prior to the discovery of oil in the Niger Delta, the traditional occupations of the people of the Niger Delta are fishing, farming and petty trading. However, the advent of multinational oil companies, land, which utilised for subsistence farming were acquired by government parastatals, multinationals companies, and other big industrial establishments thus dispossessing the people of their 
farmlands and were acquired with little or no compensation [46]. These lands were polluted by multinational company's activities as rivers, streams and creeks pollution and debased the fishing occupation. Furthermore, multinational companies settled the youths with insignificant sums of money rather than train them to acquire relevant skills for self-reliance, despite the fact that these multinationals earn high profits and fail to reinvest surplus capital and do not create job opportunities for youths [41].

Also the political system of Nigeria is superstructure which contributes largely to youth restiveness in the country as the economy has been severely plundered by public office holders. Most sectors of the economy collapsed as a result of cumulative mismanagement, unbridled corruption and opulence on the part of public office holders [1]. Chukuezi [33] stated that political power holders and the bureaucratic elite see their position as leverage to wealth at the expense of the masses which is perpetuated by the balkanisation of the economy. Politicians impose candidates on the people against the will of the majority. Therefore, politicians go into office and engage in embezzlement and corrupt enrichment in order to pacify their political godfathers. Furthermore, Nwiyi [47] subscribed to the view that government officials loot the Nigerian national treasury, which has made youths resort to violence and intimidation to acquire wealth.

Peer group influence cannot be discounted. Our youths are neck-deep in accessing pornographic websites on the internet, joining secret cults, and smoking, drinking, fornicating, partying and generally being unruly. Studying hard at school is now a thing of the past. The yardstick for measuring greatness for youths today includes the above-listed social vices. Over 80 per cent of the crimes committed in the society are perpetuated by youths who want to achieve millionaire status by hook or crook means. Nigeria's recent poor performance in continental and world sports is a testimony to youth's apathy in the country.

Another major cause of youth restiveness is the sociocultural factor that has accentuated the tempo of youth restiveness. A good example is the chieftaincy squabbles and incessant internecine wars. The Niger-Delta is replete with causes of chieftaincy arguing especially in oil bearing communities. People struggle to be made chiefs in order to corner oil royalties of their communities, which has caused cases of fighting, bloodletting, and crises and the youths play immensely a significant role under the rubrics of Community Development Committees [47].

Therefore, Youth restiveness can also result from blatant refusal on the part of companies to obey traditions and customs of host communities. For example, if a company acquires a parcel of land where there is a deity, the community may insist on the performance of certain rituals to appease the deity. But if such demands are not met, it may result in violent protests, demonstrations and youth restiveness.

\subsection{Government and Youth Restiveness Eradication}

Youth restiveness in Nigeria today has become devastating and has constituted one of the securities concerned to both individuals and the society in general. Youth which are considered as leaders of tomorrow are turned to be society destroyers since they were mostly involved in all conflicts and violence that the country suffers [42]. Obviously, government has not been reluctant to the phenomenon, but the strategy adopted in curving most the restiveness in Nigeria was more of repressive and violence acts through the deployment military and police to curve the menace. For instance in Niger-Delta despite the amnesty declaration, the government continues to use reprisal means to suppress the restiveness in the area.

Again, the development commissions, boards and ministry established by the government as the responds to the demands of the people never made any meaningful achievements rather the serves as avenue for self-enrichment and corruption at the expense of the poverty stricken masses of the region [33]. The state of insecurity in the contemporary Nigeria is no more a news. But the worrisome is the way and manner which the leaders are handing the state of affairs [48].

Furthermore, Alubo [48] stated that Nigeria's government offered a sixty day amnesty to Militants willing to trade their weapons for promises of immunity from persecution and access to vocational training. The insecurity in the NigerDelta region has grown to another level where everyone can be kidnapped. Today expatriates go through the agony when kidnapped and the trauma is unimaginable. Securing the pipelines and other oil and gas assets in the country has become a heavy burden to the government; because it is on record that this insecurity problem the federation loses. Since the hostility began, very few investors have come into the region because, no one will naturally invest in an insecure environment. Many companies with considerable investment have moved headquarters from the region to other parts of the country. The insecurity issue drifts off investors away from the aggravated region and now most of these companies now maintain only skeletal services in the region, which brings up the problem of unemployment and that in turn makes the youth to indulge in violent activities [49].

\subsection{Governmental Challenges in Eradicating Youth Restiveness in Nigeria}

Insurgency in whatever form is considered serious security threat to a nation. However, it is important that issues leading to insurgency are often associated with the people's grief against the state or state institutions. There is the need therefore to always handle such cases with care and diplomacy, so that it does not result in complete breakdown of law and order [49]. Alubo [48] explained that Nigeria pursued economic interests at the expense of secure and stable environment in the Niger Delta region. At the objective level, the Nigeria has proved incapable of alleviating the critical development gaps in the creeks. At the subjective level, the militants are young, educated and have modern technology to their advantage. As the Niger Delta conflict escalated, it led to a very disturbing national (even sub regional) security concerns. The regional waterways in the 
Gulf of Guinea became increasingly risky for any form of business, including fishing. It reduced the frequency of mercantile ship movement and threatened to heighten regional tensions.

The corruption of Nigerian political process that has left the oil mineral-producing communities of the region poor and undeveloped has produced an unintended consequence. According to Herskovits [50], the present situation in Nigeria especially as it relates to the rising level of insurgency, can only be understood when viewed in the light of the fact that over the years, the leadership lacked three major and ancillary leadership elements which ought to represent what Nigerians should admire in any future candidate for the highest office of the land., in his analysis these include, vision for society and people, commitment to vision, purposefulness and will to achieve major aspects of vision and the humanistic tendency of the leader.

According to Okujagu [51], Nigerian State is a victim of high-level corruption, bad governance, political instability and cyclical legitimacy crisis. Consequently, national development is retarded, and the political environment uncertain. The country's authoritarian leadership faced a legitimate crisis, political intrigues, in an ethnically differentiated polity, where ethnic competition for resources drove much of the pervasive corruption and profligacy. While the political gladiators constantly manipulated the people and the political processes to advance their own selfish agenda, the society remained pauperised, and the people wallowed in abject poverty. This invariably led to weak legitimacy, as the citizens lacked faith in their political leaders and by extension, the political system. In the same manner, Ololube [52] observed that Nigerian government remained distant from serving the interest of its people. Politics at the federal, state and local levels of the Nigerian federation are dominated by the powerful mandarin who built vast patronage networks during the military days and who now use political office to expand these networks and their personal fortunes. Moreover, many of these so called "godfathers" have been cultivating personal militias to secure their positions, prompting a local arm race in some regions.

The rising level of corruption in Nigeria, nonchalant attitude on the part of the government and massive embezzlement of public funds especially from the 1980's led to the myriad of unemployed youths who became willing tools in the hands of corrupt politicians to unleash terror on their perceived enemies as well as other related state (which include the police and other related security agencies). It was indeed these situations that breed what an analyst later came to describe as the Talibans of Nigeria (which later became Boko Haram Sect). This group consisted of Nigerian university undergraduates, former military personnel and professionals, who felt dissatisfied with the level of irresponsibility exhibited by the Nigerian government and those around the corridor of power [53].

Practical Measures in Curbing Youth Restiveness

The phenomenon of youth restiveness has attracted tremendous interest and attention especially as it affects industrial harmony and peace in the Niger-Delta. OkorosayeOrubite [54] contended since crude oil is the sustainer of the Nigerian economy, the people of the Niger-Delta would be best served by the multinationals who should lay the foundation for development of self-reliant communities and a sustainable environment, Restoration of community land, and environment-friendly policies are some of the things that can stem the tide of frustration, youth restiveness and violence. Idumange [55] identified neglect as the main cause of youth restiveness and the cardinal issue is the uneven distribution of revenues accruing from crude oil. He suggested oilbearing communities should not only be entitled to compensation arising from ecological genocide, but also a depletion allowance because oil is a non-renewable resource. Furthermore, oil companies should train youths in skills relevant to operations, as this will enhance employability.

Government should also embark on youth empowerment programs to enable youths to engage in meaningful activities. Job creation for youths is essential while skills acquisition programs are a sine qua non. Skills acquisition programs should emphasize the non-formal factor. Youths should be trained as vulcanizers, welders, carpenters, mechanics, etc. to be self-employed. School-toland and poverty eradication programs should be vigorously pursued to enable youths to advance their chosen career for survival and selfactualization. Alafonye [56] has provided guidelines for developing youth projects which include a clear understanding of the constraints impairing the development and success of youths in the region, developing industryspecific guidelines for improving and strengthening managerial skills of youths, and providing financial grants for youths to establish small-scale industries.

Measures could be added by the award of scholarships and bursary allowances, sports development and other creative activities that would engage youths. There can be no solution to the simmering conflict in the oil producing areas of the Delta until its people gain the right to participate in their own governance and until the protection of the rule of law is extended to their communities. The injustices facing the people of the Delta are in many ways the same as those facing all Nigerians after decades of misrule by oligarchs. In the oil producing regions, suppression of political activities, lack of legal redress for damages to the environment and the resulting loss of livelihood, and sheer ubiquity of human rights abuses by regional security forces have generated unnecessary tension [57].

The first responsibility for resolving these injustices lies with the Nigerian government. Yet multinational oil companies operating in Nigeria cannot avoid their own share of responsibility. While the political environment in Nigeria is as difficult for the oil companies as it is for anyone else, and that the oil industry does not have the power to alter government policy towards the oil regions, oil companies in many respects contribute towards discontent in the NigerDelta and to the conflict within and between communities that results in repressive government responses [57]. Oil companies must take steps to ensure oil production does not 
continue at a cost to host communities. There is an evergrowing likelihood, unless corrective actions are taken, protest in the Niger Delta will become violent in an organized and concerted way, with consequent reprisals and worsening of the security situation that will harm all those with interests in the Delta region, whether residents or companies.

\section{Summary of Findings, Conclusion and Recommendations}

Findings of the study revealed that youth restiveness is a social vice that is giving the nation sleepless nights. The problem of youth restiveness on the economic development of Nigeria especially in the Niger delta region is that it deals with the long period of tolerance by the youths of the oil producing communities. This study identified that illiteracy, unequal distribution of natural resources, poor child upbringing, unemployment, poverty among these causes of youth restiveness. Illiteracy among Nigerian youths has been a thing of concern to many citizens. Knowledge and education acquired by individuals most often help them in their levels of patriotism, value orientations and healthy lifestyles. Population Reference Bureau [58] observed that $30 \%$ of Nigerian youths were not enrolled in secondary schools. Hence, the findings agree with Yesufu [59] assertion that most youths that did not have access to formal education are talks for restiveness.

This study agreed with that of Chukwuemeka and Aghara [40] that incidence of marginalization, denial of social right, environmental degradation and economic devastation activities by the Government of Nigeria had triggered off the irate youths in the Niger-Delta region to involve in all sorts of restiveness in demand of their right. This scenario also agreed with the work of Elegbeleye [9]. In the same vein, Ofem and Ajayi [37] agreed with the findings of the study shows that youth restiveness is associated with lack of humanitarian and social welfare, lack of good governance, corrupt practices of government officials, inadequate training programmes, unemployment and lack of quality education. This indicates that causes of youth restiveness are multifaceted in nature. It therefore means that curbing youth restiveness in Nigeria might also take multidimensional approach.

Findings also showed the effects of youth restiveness on Nigerians. The study identified upsurge of social vices and crimes (cultism, kidnapping, armed robbery, hostage, abduction) among others and destruction of lives and properties. Incidences of such seem to be on the increase in our society in recent years. These have also been linked with youths either from Nigeria or neighbouring country Niger. Chukwuemeka and Aghara [40] agreed that the invasion of the multinational oil companies by restive youths in the Niger-Delta, the abduction and kidnapping of foreign nationals working in oil companies, the incessant harassment of traders in Lagos and the every-day-clash in Jos are outcomes of youth restiveness in the country.

The study discovered an increase in unemployment rate. This definitely might be due to some individuals leaving their business and other jobs relocating from high security risk areas. Such areas of high rate of youth restiveness discourage investors. Zakaria [10] agrees that youth restiveness increases youth unemployment. He however asserted that the absence of job opportunities in developing countries like Nigeria is responsible for youth restiveness with disastrous consequences.

The study identified skill acquisition programs, enlightenment campaigns, and formal education among others. Mutiba [31] affirmed that education is the primary conduit for value formation. While preparation for examinations is afforded priority, value formation, character building, and focusing on building ethical standards in children regrettably are not given adequate emphasis in school curriculum. For formal education to help curb youth restiveness in the country our education has to be modeled towards value inculcation and citizen education at all levels of our education. Our education must be made to be functional meeting the students' needs. More emphasis should be placed on vocational and technical education which will help students acquire skills that will introduce them to entrepreneurship development.

The study concluded that the development of youths is paramount to the development of Nigeria as a country in every form especially economically. Also, with adequate and due measures youth restiveness can be curbed; Nigeria youths can achieve their potentials and participate actively in both local and international affairs which can contribute immensely to the growth of the country's development. The study therefore recommended that:

1. The Government should pay more attention to the needs and demands of the youth of the country by creating avenue for scholarships, entrepreneurship loans and even skill acquisition programs.

2. Youths should be effectively advised to engage in any legitimate work and avoid any form of idleness by sourcing for jobs.

3. Enlightenment campaigns against youth restiveness are also important; citizens would be educated on the damage youth restiveness brings to the society and this information can help them avoid any form of youth restiveness.

4. Oil companies operating in the Niger delta region should pay a greater percentage of fees direct to the host communities. This percentage of fees paid can be seen as compensation for the damage done to the host communities land.

5. Amnesty programs in the country which promises a better future for both the local population (i.e. the host communities) and the companies if well managed should be brought up. This means that the government should find common grounds that will benefit the host communities and the oil companies so as to avoid any form of conflict. 
6. The immoral activities of those who sponsor and spur the youths into restiveness for their own selfish ambition should be checked. Youths that engage in youth restiveness always have people who sponsor them to carry out their violent acts, such people only enhance these youths for their selfish gains.

7. People in government who embezzle and hoard funds specifically given to address problems in the NigerDelta should be prosecuted and be made to face the law.

If these recommendations are followed, Nigeria in the nearest future would have avoided what may have become like a war zone which can cause its economy becoming relatively poor.

\section{References}

[1] Igbo, H. \& Ikpa, I. (2013). Causes, Effects and Ways of Curbing Youth Restiveness in Nigeria: Implications for Counselling. Journal of Education and Practice, 4 (6), 131-137.

[2] Osalor P. (2012) Youth Restiveness and Unemployment in Nigeria: The Way Out part 1.

[3] Lamido S. (2012) Youth Violence in the North: the Boko Haram Sector.

[4] Ololube, N. (2011). Education and Society: An Interactive Approach. Owerri: Springfield Publishers.

[5] Winston S. C (2013) Economic Development: City of Winston-Salem North Carolina.

[6] Amartya S. (1999) Discovering development. The Dreams and Damage.

[7] Girigiri, B. (2017). Issues in the Problems of Youth Restiveness; Niger Delta Contact. New Owerri: Springfield Publishers.

[8] Abudah K. B. (2004). Alternative Dispute Resolution in Niger. Law Practice J., 2 (1): 6.

[9] Elegbeleye, O. (2015). Recreational Facilities in Schools: A Panacea for Youth Restiveness. Journal of Human Ecology, 93-98.

[10] Zakaria (2006). Curbing Youth Restiveness in Nigeria: The Role of Information and Libraries.

[11] World Bank (1992): World Bank Annual Report 1992 (English).

[12] Aruthur L. (1954). The Economy of Loyalty Contracts: Model of Structural Economic Growth and Development.

[13] Eliagwu (2008). Conflict Resolution through Dialogue in the Niger Delta: Youth Restiveness and Socio-Economic Development.

[14] Onah (1999) Social Conflict in the South-South Nigeria: Implications for Foreign Investment.

[15] Gurr T. (1970). Why Men Rebel.

[16] Coleman J. (1966). Socio-economic Development of the various Ethnic Groups.
[17] Asobie (2004). Niger Delta Youth Restiveness and SocioEconomic Development of Nigeria: Academic Journals.

[18] Saro wiwa K. (2006). Ethnic Minority Conflicts and Governance in Nigeria: A Case Study of Rivers State.

[19] Chen X. (2015). Status Concern and Relative Deprivation in China: Measures, Empirical Evidence, and Economic Policy.

[20] Wilson J. Q and Kelling G. (1982). Broken Windows: The Police and Neighbourhood Safety (From Criminal Justice System: Politics and Policies).

[21] Lemo, T. (2013). "Policy and Execution" in "Development and the Entrepreneurial Challenge" (11th January, 2013). Available online at accessed on 15th June, 2018.

[22] Yahaya, M. (2016). Poverty Alleviation Programme as a Means of Fostering Nigeria Nationhood. The Project YES Experience. Minna. Gurara J. Human. Stud. 3 (2): 50-51.

[23] Yusuf, S. (2016). Youths and National Orientation. In A. A. Adegoke (Ed.) Proceeding of the 25th National Conference of the Counseling Association of Nigeria 11-15.

[24] Central Bank of Nigeria (2017). CBN Briefs (2014-2015 Edition). Abuja: Research and Statistics Department of Central Bank of Nigeria.

[25] CBN "Annual Report and Statement of Accounts" 2017, (Central Bank of Nigeria.).

[26] Asamu, F. (2016). Ethnic Militias and National Security. In J. F. Hassan S. Ebele. A (Ed.), Democracy and Development in Nigeria, Social Issues and External Relations (Vol. 3).

[27] Abdullahi, S., Mohammed I. Z., \& Casey, C. (2011). Studies in Cultural Sociology. Ibadan: Foludex Printers.

[28] Haruna, A and Jumba, A. H. (2017). Politics of Thuggery and Patronage in the North Eastern Nigeria. Journal of Academic Research International, 1 (1), 111-119.

[29] Chukwuemeka, E. (2015). Bourgeoisie against Peasants: A Political Diagnosis of the Evil Consequences of Multinational in Africa. Journal of Interventional Studies 1 (2), 45-50.

[30] Coleman, J. (2010). Nigeria: Background to Nationalism. Benin City: Borburg and Winston.

[31] Mutiba, B. (2017). Inculcating values the Need of the Hour: And Curbing Youth Restiveness for National Peace, Transformation and Development.

[32] Ifidon, S., \& Ahiauzu, B. (2015). Information and Conflict Prevention in the Niger Delta Region of Nigeria. African Journal of Libraries, Archives, and Information Science. 15, (2): 125-132.

[33] Chukuezi, C. (2014). Poverty and Youth Restiveness in Nigeria: Implications for National Development. Ozean Journal of Social Sciences, 2 (2), 97-103.

[34] Chika, P.. \& Onyene, V. (2010). Youth restiveness in the Niger Delta of Nigeria: Implication for education and leadership. European Journal of Social Sciences 18, 2, 286296.

[35] Okaba, B. (2015). Petroleum Industry and the Paradox of Rural Poverty in the Niger Delta Benin City: Ethiope Publishing. 
[36] Ndu, A. (2012). The role of family in managing indiscipline among youths in Nigeria. Journal of Counselling Psychology. $1,45-51$.

[37] Ofem, N.., \& Ajayi A. (2016). Effects of youth empowerment strategies on conflict resolutions in the Niger Delta of Nigeria: Evidence from Cross River State. Journal of Agriculture and Rural Development 6 $(1,2)$ : 139-146.

[38] Emaduku. A. (2016). Youth Restiveness, Militancy and the Intractable Problems of the Niger-Delta.

[39] Onyekpe, N. (2011). Managing youth at election. The Constitution: A Journal of Constitutional Development. 7, (1): 76-87.

[40] Chukwuemeka, E. Anazodo, R. \& Nzewi, H. (2011). Social conflict in the south-south Nigeria: Implications for foreign investment. African Journal of Political Science and International relations 5, 335-340.

[41] Anasi S. (2010) Curbing Youth Restiveness in Nigeria: The Role of Information and Libraries.

[42] Inyang, B. (2016). "Tackling Unemployment Hurdles in the fragile economies of the Niger Delta region of Nigeria". In the international observer. 1 (2), 196-200.

[43] Okojie, U. (2016). "Impact of Niger Delta crises on Nigerian Economy". In the Nigerian. Journal of Research and Production. 15 (2), 106-110.

[44] Ololube, N. (2015). Understanding Teachers Professional Competencies for Education Effectiveness. Owerri: SpringField Publishers.

[45] Chukwuemeka, E. \& Agbara, V. (2010). Niger Delta youth restiveness and socio-economic development of Nigeria. Educational Research and Reviews 5, 7, 400-407.

[46] Okoko, K. and Nna J. (2015). "Federalism and Resource Allocation: The Nigerian Experience". Nigerian Journal of Oil and Politics. 1 (1), 16-35.

[47] Nwiyi, G. (2017). Education, youth restiveness and unemployment: Implication for national development. Port Harcourt, Nigeria: Rodi Printing \& Publishing.

[48] Alubo, O. (2012). Sociology: A Concise Introduction. Jos, Nigeria: Ichejum. press Ltd.

[49] Anioke, U. (2012). Conflict Resolution in the Local Government" paper Presented in a workshop, organised by Local Government Service Commission, Enugu.

[50] Herskovits, J. (2012). In B. a. Sule (Ed.), Pupolar Participation and Democrazation in Nigeria Under Youth Republic. ARADA.

[51] Okujagu, A. (2017). Morality, Religion (Faith) and Philosophy (Reason). Port Harcourt: Edison International.

[52] Ololube, N. (2012). Sociology of education and society: An interactive approach. Owerri: Springfield Publishers.

[53] Ibaba, S. (2015). Understanding the Niger Delta Crisis. Port Harcourt: Amethyst and Colleagues Publishers.

[54] Okorosaye-Orubite, A. (2015). Education and Sustainable development in the Niger Delta: The Role of the Youth. International conference on the Nigerian state, oil industry and the Niger Delta. Port Harcourt, Nigeria: Harey Publications.
[55] Idumange, J. (2018). Dynamics of Oil Style Insurgency in the Niger Delta, Implications for Educational Development. Owerri, Nigeria: Springfield publishers.

[56] Alafonye U., ololube N. P, egbezor (2014) Academic Background, Socio-Economic Status and Gender: Implications for Youth Restiveness and Educational Development in Rivers State.

[57] Asobie A (2014). Conflict Resolution and Human Rights: A case study approach Ibadan: E Watch Print. Chukwuemeka, Emma (2008) Prnciples of Human and Personnel management in Nigeria, Enugu: HRV Publishers.

[58] Population Reference Bureau (2016): World Population Data Sheet.

[59] Yesufu, T., (2016), The Nigerian Economy: Growth without Development. The Journal of Uni. Benin Social Science Series for Africa.

[60] Abdullahi A. (2012) A review of youth violence theories, developing interventions to promote sustainable peace in Ilorin.

[61] Adewuyi, T. (2008). Utilization of self-counselling theories for youth peer relationship. The Lagos Counsellor. 1, 1, 5-21.

[62] Akintoby, B., and Cinyabuguma, M., 2004, Sources of Growth in the Democratic Republic of Congo: A Cointegration Approach. IMF Working Paper, 04 (114).

[63] Akintoye, A. (1999). Zango-Kataf Crises: A Case Study in Otite. Ibadan: Alberts formation, Spectrum Books.

[64] Arowosegbe J. (2007) Violence and the national development in Nigeria, the political economy of youth restiveness in the Niger delta.

[65] Capasso, S., (2006), Stock Market Development and Economic Growth, Research Paper. No. 2006/102, United Nations University, World Institute for Development 21 (1).

[66] Essien, E. and Bawa, E., 2007, Explaining Growth: A CrossCountry Analysis of West African Monetary Zone (WAMZ)" CBN Economic and Financial Review vol. 40. Setp.

[67] Essien, E., 2002, Nigeria's Economic Growth: Performance and Determinant, CBN Economic and Financial Review, 40. (3).

[68] Federal Republic of Nigeria (2001), National Youth Development Policy, Programme and Implementation Strategies, Nigeria, Abuja.

[69] Girigiri (2007) The challenges of youth restiveness and educational development In rivers state.

[70] Gotep M (2000). The contribution of social studies education towards nation-building. Social -Studies Quarterly 3 (1): 116119.

[71] Iyayi, F. (2013). "Poverty in the Niger Delta". A Paper Presented at the Meeting on Poverty Eradication October 3. Pp. 2.

[72] Lawal, H. (2013). Teacher Education and the Professional Growth of the 21 st Century Nigeria Teacher. The African Symposium, 3 (2).

[73] NBS \& Ministry of Youth and Development. (2013). National Baseline Youth Survey Report. Abuja. 
[74] Nwanna-Nzewunwa, O. (2016). Niger Delta Crisis: Yesterday and Today. Owerri, Nigeria: Springfield Publishers.

[75] Obuh, J. (2015). Youth involvement in rural development activities in Ogba district of Rivers State, Nigeria. Journal of Agriculture and Social Research, 5 (1), 48-53.

[76] Odedokun, Mathew. O., 1997, Factors Responsible for Poor Economic Growth Performance in Africa in 1970s and 1980. A Cross -sectional evidence from 42 Countries.

[77] Ogbulu, M., 2009, Capital Market Development and Economic Growth: Application of Co-integration and Causality Tests, Journal of Finance, Banking and Investment, Abia State University, Uturu Nigeria.

[78] Ojakorotu, V., and Gilbert, L. (2010). Understanding the Context of Oil Violence in the Niger Delta of Nigeria. Johannesburg.
[79] Oluwasegun Ayokunle. [2013]. Youth Empowerment And Development Drive-An Invaluable Step To Secure Nigeria's Future Prosperity.

[80] Romer, P,. (1994), The Origin of Endogenous Growth, The Journal of Economic Perspective, vol. 8, Issues (Winter).

[81] The Tide news curbing youth restiveness in Niger delta.

[82] Wikipedia (2013). Youth Empowerment. Last modified on 12th April, 2013.

[83] Yusuf Abdu Yusuf (2014), Youth restiveness: Nigeria's security and sustainable development.

[84] Zeillner, Arnold., 1979, Causality and Econometrics, Carnegie-Rochester Conference Series, 10, K. Brunner and A. H. Meltzer, eds. North Holland Publishing Coy. Amsterdam. 